Azure E. Bevington $^{1 *}$, Robert R. Twilley ${ }^{2}$, Charles, E. Sasser ${ }^{1}$, Guerry O. Holm Jr. ${ }^{3}$

\title{
Contribution of river floods, hurricanes, and cold fronts to elevation change in a deltaic floodplain, northern Gulf of Mexico, USA
}

${ }^{1}$ Department of Oceanography and Coastal Sciences, Louisiana State University, Baton Rouge, LA 70803

${ }^{2}$ Louisiana Sea Grant, Department of Oceanography and Coastal Sciences, and Coastal Studies Institute, Louisiana State University, Baton Rouge, LA, USA 70803

${ }^{3} \mathrm{CH} 2 \mathrm{M}, 700$ Main Street, Suite 400, Baton Rouge, LA 70801

*corresponding author:

Azure E. Bevington, azure@ lsu.edu, (225) 578-8810 phone, (225) 578-6423 fax

\begin{abstract}
Deltas are globally important locations of diverse ecosystems, human settlement and economic activity that are threatened by reductions in sediment delivery, accelerated sea level rise, and subsidence. Here we investigated the relative contribution of river flooding, hurricanes and cold fronts on elevation change in the prograding Wax Lake Delta (WLD). Sediment surface elevation was measured across 87 plots, eight times from February 2008 to August 2011. The high peak discharge river floods in 2008 and 2011 resulted in the greatest mean net elevation gain of 5.4 to $4.9 \mathrm{~cm}$ over each flood season, respectively. The highest deltaic wetland sediment retention (16.3\% of total sediment discharge) occurred during the 2008 river flood despite lower total and peak discharge compared to 2011. Hurricanes Gustav and Ike resulted in a total net elevation gain of $1.2 \mathrm{~cm}$, but the long-term contribution of hurricane derived sediments to deltaic wetlands was estimated to be just $22 \%$ of the long-term contribution of large river floods. Winter cold front passage resulted in a net loss in elevation that is equal to the elevation gain from lower discharge river floods and was consistent across years. This amount of annual loss in elevation from cold fronts could effectively negate the long-term land building capacity within the delta without the added elevation gain from both high and low discharge river floods. The current lack of inclusion of cold front elevation loss in most predictive numerical models likely overestimates the land building capacity in areas that experience similar forcings to WLD.
\end{abstract}

\section{Keywords}

deltas; sedimentation; cold fronts; hurricanes; river floods; deltaic floodplain wetlands; USA, Louisiana, Wax Lake Delta 
Land building by both progradation and aggradation in coastal deltaic wetlands is largely

3 controlled by sediment delivery and deposition from terrestrial sources via fluvial sediment

4 transport and marine sources, such as offshore bay bottom deposits resuspended by waves, tides

5 and storms. Understanding the relative contribution of these sediment delivery processes to net

6 elevation change is important for prediction and management of deltas in the $21^{\text {st }}$ century

7 (Georgiou et al. 2005; Day et al. 2007; Paola et al. 2011). Coastal deltas are globally important

8 as population centers, (Ericson et al. 2006; Syvitski et al. 2009) and also include extensive and

9 diverse ecological communities, including mangrove forests, salt, brackish and fresh marshes

10 (Day et al. 2008). The processes that have controlled delta formation throughout the Holocene

11 are changing, including accelerated sea level rise, sediment trapping in river basins by dams and

12 reservoirs, human induced increases in compaction and subsidence due to fluid extraction,

13 reduction of distributary channels and an increase in storm intensity and frequency, altering the

14 ability of deltas to persist and grow (Day et al. 2008; Syvitski 2008 Syvitski et al. 2009,

15 Vörösmarty et al. 2009).

River discharge and sediment delivery control a large portion of the land-building in

17 deltaic systems, for example the shift from progradation to retrogradation that was observed in

18 the Danube Delta as a result of a decrease in sediment delivery of 30-40\% due to dam

19 construction within the past $40 \mathrm{yr}$ (Panin and Jipa 1997). A loss in wetland area in the Yellow

20 River Delta has also been attributed to decreases in water and sediment delivery (Li et al 2009).

21 Marine processes can also have strong effects on delta growth; the Ebro Delta in Spain is a

22 sediment limited system where waves, tides and storms primarily shape delta morphology 
23 (Jiménez et al. 1997, Valdemoro et al. 2007). The physical processes that shape the Mississippi

24 River Delta (MRD), in the northern Gulf of Mexico, include river flooding, frequent winter cold

25 front passage (20-30/yr), tropical cyclone landfall (return interval of 3-10 yr) and a

26 predominantly east to west longshore current. Wave energy is typically very low, with wave

27 heights between 0.5 to $1 \mathrm{~m}$ with a period of 5 to $6 \mathrm{~s}$ and a mean tidal range of 0.35 to $0.43 \mathrm{~m}$

28 (Hardy and Henderson 2003, Georgiou et al. 2005, Keim et al. 2007). Given the low energy of

29 these coastal forcings relative to river discharge, the MRD is considered a fluvial-dominated

30 system in the classic ternary diagram (Galloway 1975).

There has been much recent analysis looking at the variability in the amount of sediment reaching the coastal zone and its capacity to reduce land loss that is occurring there (Turner et al. 2006, Tornqvist et al. 2007, Blum and Roberts 2009, Allison et al. 2010, CPRA 2012, Rosen and Xu 2014, Nittrouer and Viparelli 2014, Roberts et al. 2015). Previous studies have generally

35 focused on one type of forcing (e.g. floods, storms or cold fronts) and lack direct comparisons of the contribution of multiple forcings to coastal land loss and gain. Here we used observations

37 made in the Wax Lake Delta (WLD), a young ( $<50 \mathrm{yr})$ prograding delta lobe of the Mississippi River, to investigate the relative contribution of three seasonally distinct hydrologic forcings on 39 sediment surface vertical elevation change. River flooding, hurricanes and repeated cold front 40 passage occur within this system during distinct times of the year and will be referred to 41 throughout as seasonal forcings. We investigated the variability between seasons and among 42 years, as well as in terms of the long-term return period of rare events such as large floods and 43 hurricanes, to better understand and predict how modern progradational deltas build over long 44 timescales. This study is the first to directly compare the empirically measured contribution of all 45 three forcings to elevation change in coastal deltaic wetlands. 
Large river floods generally result in appreciable land building along the remaining

47 unleveed Mississippi River distributaries, and account for the majority of land building observed

48 in deltaic wetlands (Rouse et al. 1978; Roberts and Adams 1980; Majersky et al. 1997). The loss

49 of flood derived overbank sedimentation is a major factor in increasing rates of wetland

50 subsidence and land loss within the MRD (Baumann et al. 1984; Day et al. 2007; Day et al.

51 2008; Syvitski et al. 2009; Vörösmarty et al. 2009).

The influence of tropical cyclone passage (both tropical storms and hurricanes) on deltaic

53 sedimentary processes can be large, though they are generally too rare to result in total

54 readjustment of the delta morphology (Syvitski 2008). The factors that determine the severity of

55 hurricane storm surge include aspects of the storm itself, including but not limited to direction of

56 approach, forward speed, wind speed, integrated kinetic energy of the surface wind field, and

57 central pressure (Georgiou et al. 2005; Powell and Reinhold 2007; Irish and Resio 2010). The

58 coastal morphology is also a strong factor in the resulting severity and pattern of hurricane surge

59 inundation, with the broad low-lying MRD acting to enhance storm surge (Westerink et al. 2008;

60 Dietrich et al. 2011) The return period of all tropical cyclones (wind speed $\geq 63 \mathrm{~km} \mathrm{hr}^{-1}$ ) in the

61 vicinity of the MRD is every $3 \mathrm{yr}$ and for hurricanes (winds speed $\geq 119 \mathrm{~km} \mathrm{hr}^{-1}$ ) is every 7 to 10

62 yr (Keim et al. 2007).

Sediment redistribution and deposition on the surface of coastal wetlands as a result of

64 the large hurricane storm surges has been reported across the northern Gulf of Mexico, with

65 deposition ranging from washover of sandy beaches and barrier islands that extends 100s of

66 meters from the coast (Williams 2009; Morton and Barras 2011) to widespread redistribution of

67 fine grain sediment and organic root mats that extends to interior marshes $10 \mathrm{~s}$ of $\mathrm{km}$ from the 
coast. While a few studies focused solely on deposition (Turner et al. 2006; Tweel and Turner 2012), many have also reported on the widespread erosion that resulted from tropical cyclone passage (Baumann et al. 1984; Rejmánek et al. 1988; Guntenspergen et al. 1995; Nyman et al. 1995; Cahoon 2006; McKee and Cherry 2009; Morton and Barras 2011). It is very difficult to determine both erosional and depositional processes associated with these storms across the entire coast because the effects of each storm are unique based on factors such as angle of approach, size, wind speed, wave height, storm surge, and tidal stage, as well as the variability in coastal wetland morphology, dominant vegetation type and density, sediment characteristics and coastal built infrastructure such as levees, canals, and impoundments, which can affect sedimentary processes.

\section{southeastern U.S. A cold front is the common term for the transition zone between two} atmospheric air masses of different densities that generates a predictable set of wind, wave and current conditions as it moves through the coastal zone (Mossa and Roberts 1990). Generally the cold front passages that affect the northern Gulf of Mexico are 25 to $250 \mathrm{~km}$ wide and pass from a northwest to southeast direction every 4-7 days through between October and April, with highest occurrence in January and February. No significant variation in frequency or timing of cold fronts occurs between years, therefore their effect on coastal processes is expected to be consistent year to year (Hardy and Henderson 2003). The pre-frontal phase, typically 24-48 hours before the front passes, is defined by strong southerly and easterly winds, producing waves and currents that push water toward the coast, resulting in water level increases of 0.5 to $1 \mathrm{~m}$ over predicted levels and resuspension of sediment from coastal bays and low organic matter deltaic wetlands (Rouse et al. 1978; Roberts and Adams 1980; Mossa and Roberts 1990; Feng 
91 and $\mathrm{Li} \mathrm{2010}$; Li et al. 2011). As the front passes the coastal zone there is a sudden decrease in

92 barometric pressure and an increase in precipitation and wind speed. This is followed by the

93 post-frontal phase in which the barometric pressure rises, temperature and humidity drop and

94 winds shift to northwesterly and northerly direction. These strong post-frontal winds move water

95 out of coastal bays, rapidly decreasing water levels and transporting suspended sediments onto

96 the continental shelf (Walker and Hammack 2000). The resuspension and transport of sediment

97 from shallow bay bottoms in the vicinity of both the WLD and the nearby Atchafalaya Delta has

98 been well established with predominant westward longshore sediment transport and deposition

99 on the shallow continental shelf and coast of the Chenier Plain located in western Louisiana

100 (Roberts et al. 1989; Mossa and Roberts 1990; Allison et al. 2000; Draut et al. 2005; Neill and

101 Allison 2005; Kineke et al. 2006; Moeller et al. 2012). Water level changes due to cold front

102 wind conditions are often referred to as meteorological tides, defined as the difference between

103 the predicted astronomical tide and the total observed water level (Pugh 1996). In the northern

104 Gulf of Mexico this large change in water levels of $1 \mathrm{~m}$ or more over 24-48 $\mathrm{hr}$ and their frequent

105 reoccurrence from October to April can have a much greater effect on coastal morphodynamics

106 and sediment transfer than astronomical tides alone (Georgiou et al. 2005).

Here we used the WLD as a long-term experimental system, which allowed us to isolate

108 the effects of distinct seasonal forcings. Due to its relatively protected location within

109 Atchafalaya Bay (Fig. 1) and the micro-tidal regime, the effects of astronomical tides and wave

110 action are minimal (Georgiou et al. 2005), allowing for the seasonally distinct processes of river

111 floods, cold fronts, and hurricanes to be isolated in time. In other coastal deltaic systems the

112 confounding effects of continuous and higher magnitude marine forcings would make it more

113 difficult to clearly attribute observations to a single forcing. Our original research objective was 
114 to compare the sediment surface elevation change during the spring flood period and the winter

115 cold front period with the timing and location of sampling transects designed to measure a

116 distinct seasonal interval over which each forcing was dominant and to compare seasonal and

117 interannual patterns in elevation change across the WLD. While we did not plan this a priori we 118 were also able to measure the effects of Hurricanes Gustav and Ike in September 2008. This

119 long-term sampling design has allowed us to investigate a number of questions regarding the 120 relative effect of the three dominant seasonal forcings, river floods, hurricanes, and cold fronts,

121 on sediment surface elevation change.

\section{2. Methods}

\subsection{Study area and seasonal intervals}

The WLD is a prograding delta forming at the terminus of the Wax Lake Outlet (WLO), a constructed distributary channel of the Atchafalaya River, which is a major distributary of the

126 Mississippi River (Fig. 1). The water discharge into the Atchafalaya River is maintained at 30\%

127 of the combined flows of the Mississippi and Red Rivers, and is controlled by the Army Corps of 128 Engineers at the Old River Control Structure (ORCS). The WLO was originally constructed in 1291942 as a flood control conduit from the Lower Atchafalaya River (Shlemon 1975). As the WLO 130 discharges into the shallow (2-3 m) Atchafalaya Bay the resulting bed friction forms distributary 131 mouth bars with coarse grain deposition at the bar crest (upstream end) and along the lateral 132 boundaries and finer grain sediments in the interior portions. Bars are separated by bifurcating 133 distributary channels. Over time the mouth bars increase in elevation to greater than mean low 134 low water (-0.14 m NAVD88) and become deltaic islands (Wright 1977; Wellner et al. 2005; 135 Fagherazzi et al. 2015). 
WLD is a relatively young deltaic system with prodelta deposits and subaqueous

expansion first observed in 1952. However the majority of the fine grain sediment bypassed the bay and was deposited on the continental shelf prior to the early 1970s (Shlemon 1975). Small subaerial bars that first began to appear in the WLD in 1973 grew rapidly following high river flooding and infilling of shallow lakes upstream and adjacent to the WLO (Roberts and Adams 1980; Wellner et al. 2005). Due to its unique occurance as a constructed river outlet that has been allowed to build land under natural hydrologic conditions, this system represents an extremely valuable analogue to many MRD coastal restoration strategies, which propose diverting river water and sediment into shallow coastal basins to reduce present wetland degradation rates (Parker and Sequeiros 2006; Kim et al. 2009; Allison and Meselhe 2010; Paola et al. 2011; CPRA 2012).

The WLD currently receives approximately $30-40 \%$ of the total water and sediment discharge of the Atchafalaya River (Allison et al. 2012), equivalent to 10-12\% of the total Mississippi and Red River discharge. Areal land growth rates within WLD range between 1.0 to

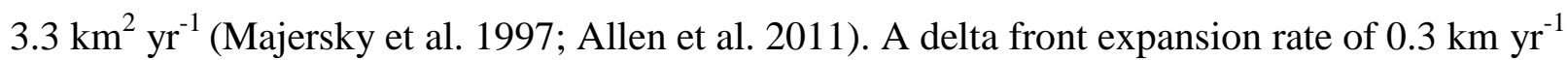
has been estimated (Parker and Sequeiros 2006), with a vertical elevation change rate estimated at $2.7 \mathrm{~cm} \mathrm{yr}^{-1}$ from 1981 to 1994 (Majersky et al. 1997). Sediment transport in the WLD is influenced by seasonal water exchange from river flooding, tidal exchange, cold fronts, and tropical cyclones (Mossa and Roberts 1990; Walker and Hammack 2000; Walker 2001; Roberts et al. 2015). During late fall, winter and 

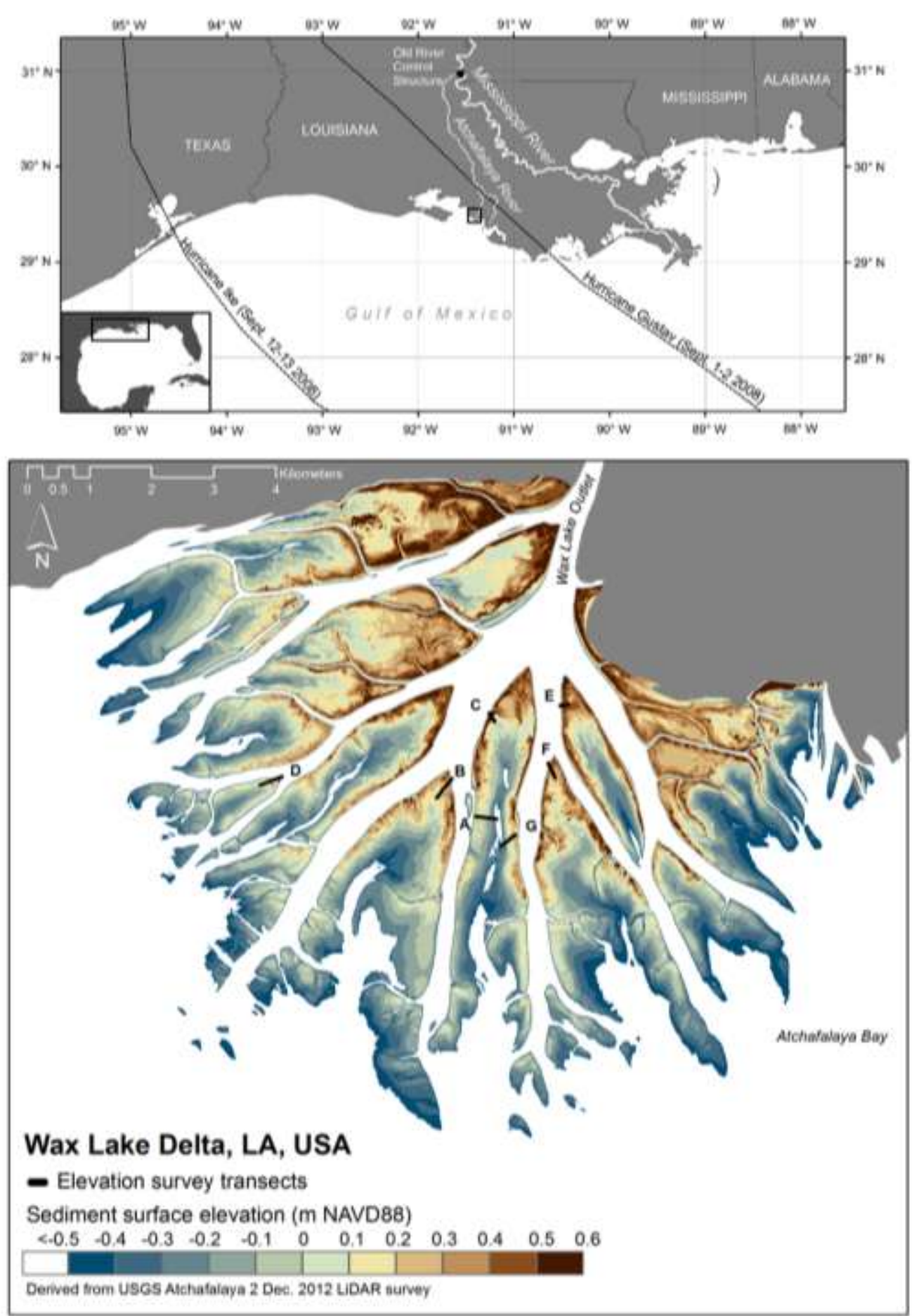

157 Figure 1. Northern Gulf of Mexico with location of study site at Wax Lake Delta. Tracks of 158 Hurricanes Gustav and Ike are also shown (top). Sediment surface elevation map of Wax Lake 159 Delta, LA, with $10 \mathrm{~cm}$ elevation ranges from 2012 LiDAR survey. Location of sampling 160 transects indicated by black lines and letters (bottom). 
162 early spring the inshore to offshore exchange of water and sediments is influenced by winds

163 associated with cold-front passage. In spring water movement is strongly controlled by the

164 increasing river discharge as the spring river flooding occurs. As river discharge decreases in the

165 summer, the microtidal regime (amplitude $\sim 35-43 \mathrm{~cm}$ ) becomes the dominant means of water

166 movement on the delta islands; however the channel discharge is maintained in a downstream

167 direction even at rising tide. The lowest river discharge normally occurs during late summer and

168 fall. This is also when tropical cyclones are most likely to occur (Walker 2001). With the

169 exception of storm surges associated with passing hurricanes and tropical storms, the WLD is an

170 entirely freshwater tidal system (Holm and Sasser 2001).

The deltaic floodplain wetlands are composed of low organic matter, highly mineral

172 sediments, primarily fine sand and silt, and are colonized by woody, shrub/scrub and herbaceous

173 fresh marsh species that exhibit zonation along the elevation gradient (Visser 1989). Similar

174 vegetation patterns have also been documented in the Atchafalaya Delta (Johnson et al. 1985;

175 Shaffer et al. 1992). Higher elevation delta islands often have a mixed canopy composed of

176 woody Salix nigra, Baccharis halimifolia and Sesbania spp. with an herbaceous understory

177 dominated by Colocasia esculenta. At slightly lower elevations mixed communities of $C$.

178 esculenta. Phragmites australis, Polygonum punctatum, Typha spp., Schoenoplectus spp., and

179 Zizaniopsis miliacea occur. Low elevation intertidal and subtidal emergent and submerged

180 herbaceous communities are dominated by Nelumbo lutea, Sagittaria platyphylla and

181 Potomogeton nodosus (Johnson et al., 1985; Shaffer et al., 1992, Bevington, 2016).

It is likely that sedimentary processes and therefore elevation change on delta island tops 
184 (Viparelli et al. 2011; Nardin and Edmonds 2014). However these effects are extremely complex 185 due to the high degree of heterogeneity of vegetion community composition in these freshwater

186 tidal wetlands, as well as the drastic seasonal shifts in aboveground herbaceous biomass. It is

187 likely that the lack of aboveground herbaceous cover during both the later part of the winter cold 188 front season and the early spring flood season may play a role in sediment surface elevation 189 change, however it occurs at a spatial and temporal scale that was not feasible to address within 190 the experimental design of this study.

\subsection{Sampling and analytical methods}

Between February 2008 and August 2011 elevation surveys were conducted before the spring river flood (February/March) and after water levels returned to non-flood levels

194 (July/August) in all years. Sampling intervals were chosen to capture the period of spring river 195 flooding and fall/winter cold front passage. Additional surveys followed the passage of 196 Hurricanes Gustav and Ike in September 2008. Due to logistical and weather constraints, field 197 surveys often consisted of 2 to 3 field days and the start and end of each season interval is 198 defined by the median field date, for example in winter 2008 field surveys were conducted on 199 January 30 and February 13, and the beginning of that interval is reported as February 7, 2008. 200 The number of days between pre-season and post-season sampling dates is referred to as the 201 sampling interval duration (Table 1). During each survey we measured the sediment surface 202 elevation along seven transects (Fig. 1, Table 2), for a total length of 1,950 m. Transects and plot 203 locations were established starting at the distributary channel edge and extended into the interior 204 of the deltaic island, This orientation was selected in order to capture a large portion of the 205 elevation gradient, which includes fringe and interior wetlands. The number of $1 \mathrm{~m}^{2}$ sampling 
206

207

208

209

210

211 campaign.

212

213

214 point of refusal. This was likely the consolidated pre-delta bay bottom mud (Roberts et al. 2005; 221 Shaw et al. 2013; Shaw and Mohrig 2013). Based on the age and consolidation of the bay bottom

Table 1. Seasonal sampling intervals, all transects sampled pre-season and post-season, change over season interval is defined as the elevation difference between the two samplings.

\begin{tabular}{lccc}
\hline Seasonal interval & $\begin{array}{c}\text { Pre-season } \\
\text { sampling }\end{array}$ & $\begin{array}{c}\text { Post-season } \\
\text { sampling }\end{array}$ & $\begin{array}{c}\text { Seasonal } \\
\text { interval } \\
\text { duration } \\
\text { (days) }\end{array}$ \\
\hline Flood 2008 & Feb. 7 2008 & Aug. 3 2008 & 179 \\
Hurricanes 2008 & Aug. 3 2008 & Sept. 16 2008 & 44 \\
Cold Fronts 2008-09 & Sept. 16 2008 & Feb. 15 2009 & 152 \\
Flood 2009 & Feb. 15 2009 & July 16 2009 & 151 \\
Cold Fronts 2009-10 & July 16 2009 & Mar. 9 2010 & 236 \\
Flood 2010 & Mar. 9 2010 & Aug. 19 2010 & 162 \\
Cold Fronts 2010-11 & Aug. 19 2010 & Mar. 1 2011 & 194 \\
Flood 2011* & Mar. 1 2011 & Aug. 21 2011 & 173 \\
\hline
\end{tabular}

* Benchmark was eroded so transect $\mathrm{F}$ was not surveyed in summer 2011 .

Sediment surface elevation was measured with a Class I laser level (Sokkia LP30A; accuracy: $\pm 1.5 \mathrm{~mm} @ 100 \mathrm{~m}$ ) and a stadia rod fit with a laser receiver (Sokkia LP100). The maximum range surveyed along any transect was $300 \mathrm{~m}$, resulting in a maximum vertical error of $\pm 0.45 \mathrm{~cm}$. Soil elevation measurements were corrected relative to temporary benchmarks, which consisted of $3.8 \mathrm{~cm}$ diameter pipes driven approximately 3-4 $\mathrm{m}$ into the sediment, to the 
222 sediments, it was assumed that any subsidence below the depth of the benchmarks was minimal 223 over the 3.5 years of sampling. Two replicate sediment surface elevation measurements were 224 taken randomly within each $1 \mathrm{~m}^{2}$ plot, and the mean value was reported as the elevation of that 225 plot. There was very little variation between plot replicates, with a mean difference of only 1.1 $226 \pm 0.09 \mathrm{~cm}$ across 640 individual plot measurements. To prevent the stadia rod from sinking into 227 the sediment the bottom was fitted with a $10 \mathrm{~cm}$ diameter plastic plate. All elevation 228 measurements were taken on bare sediment; when wrack deposits were present they were 229 carefully removed to not disturb the surface of the sediment. Bulk density cores were also 230 collected to a depth of $10 \mathrm{~cm}$ at a known volume from each elevation sampling plot, these cores 231 were oven dried to constant mass at $60^{\circ} \mathrm{C}$ and weighed to determine sediment bulk density. In order to compare elevation surveys taken at different times and different locations 233 throughout the delta, all elevation values were corrected first to the transect benchmark. Each 234 benchmark was corrected to the NOAA tidal datum, in July 2008 by linear regression analysis of 23530 minute water levels at each benchmark and verified water level data from Amerada Pass 236 (NOAA 8764227), which is approximately $10 \mathrm{~km}$ from the transects. There was significant 237 correlation for all benchmarks $\left(r^{2}>0.98\right)$. Elevations were then converted from the NOAA tidal 238 datum to NAVD88 geodetic datum, using vdatum software. It was determined that mean sea 239 level based on the NOAA tidal datum at Amerada Pass is equivalent to - $0.12 \mathrm{~m}$ NAVD88 240 (Parker et al. 2003; Shaw et al. 2013). The consistent use of the NAVD88 datum allows for 241 direct comparison to water level and elevation datasets not directly tied to the Amerada Pass $242 \quad$ NOAA tide gauge. 
The elevation change over each seasonal interval was calculated by subtracting the pre-

244 season corrected elevation from the post-season corrected elevation. The elevation change values

245 for each plot for each seasonal interval were used to calculate net elevation change (the mean of

246 all positive and negative change values), mean elevation gain (mean of only positive change

247 values) and mean elevation loss (mean of only negative change values) for each seasonal interval

248 across the entire dataset. These values were used to compare the patterns observed during the

249 different seasonal events. We also calculated mean elevation change values for $10 \mathrm{~cm}$ pre-event

250 elevation ranges for each river flood interval. Statistical analyses of elevation change were

251 conducted using SAS 9.1 (SAS Institute, Cary NC, USA), primarily one-way ANOVA unless

252 otherwise noted. Tukey's pairwise comparison with $\alpha=0.05$ was used as post hoc test, and

253 significant differences are indicated with letter values.

254 Table 2. Length of elevation survey transects, with location of first plot (located closest to

255 channel edge) all transects extended into island interior perpendicularly to channel edge.

\begin{tabular}{ccccc}
\hline $\begin{array}{c}\text { Transect } \\
\text { ID }\end{array}$ & $\begin{array}{c}\text { Latitude } \\
\text { (decimal } \\
\text { degrees) }\end{array}$ & $\begin{array}{c}\text { Longitude } \\
\text { (decimal } \\
\text { degrees) }\end{array}$ & $\begin{array}{c}\text { Total } \\
\text { length } \\
(\mathrm{m})\end{array}$ & $\begin{array}{c}\text { Number of } \\
\text { sampling plots }\end{array}$ \\
\hline A & 29.49560 & -91.44735 & 360 & 11 \\
B & 29.50113 & -91.45125 & 400 & 13 \\
C & 29.51051 & -91.44493 & 160 & 13 \\
D & 29.50171 & -91.47941 & 380 & 13 \\
E & 29.51151 & -91.43311 & 130 & 10 \\
F & 29.50315 & -91.43520 & 230 & 15 \\
G & 29.49283 & -91.44085 & 290 & 12 \\
\hline
\end{tabular}

256

Water levels over the entire sampling period were downloaded from the U.S. Geological

258 Survey (USGS) 07381590 gauge on the WLO at Calumet, LA (http://waterdata.usgs.gov), which

259 is located in the WLO channel $19 \mathrm{~km}$ upstream of the first bifurcating distributary channel of the

260 WLD, and will hereafter be referred to as WLO water level. Water levels from the NOAA 
261 Amerada Pass gauge located in the Atchafalaya Bay approximately $10 \mathrm{~km}$ southeast of the

262 WLD, more accurately represent the water level within the delta and the bay and will hereafter

263 be referred to as the WLD water level (Fig. 1). Mean daily total suspended sediment discharge in

264 short tons per day was calculated with the rating curve equation (Eq. 1) developed for USGS

265 Calumet station on the WLO (Allison et al., 2012; Allison pers. comm.). This was converted to

266 metric tons per day and used to calculate the total suspended sediment discharge for WLO over

267 each seasonal interval.

$268 \quad \mathrm{Y}=\mathrm{Y}_{0}+\mathrm{a}\left(1-\mathrm{e}^{-\mathrm{bX}}\right)$,

(Eq. 1)

269 where $\mathrm{Y}=$ total suspended sediment load (shorts tons/day), and $\mathrm{X}=$ mean daily sediment

270 discharge (cfs). Coefficients in Eq. 1 are as follows: $Y_{0}=2.057 \times 10^{4}, a=3.580 \times 10^{7}$, and b=

$271 \quad 1.883 \times 10^{-8}$.

272

A LiDAR digital elevation model (DEM) derived from the USGS Atchafalaya 2 LiDAR

273 Survey (http://coast.noaa.gov/digitalcoast/) was used to create a histogram of the deltaic wetland

274 area within $10 \mathrm{~cm}$ elevation bins. We calculated the total area within each $10 \mathrm{~cm}$ elevation bin

275 for the entire delta top equal to and over -0.5 m NAVD88. This elevation range includes the

276 majority of subtidal, intertidal and supratidal vegetated wetland habitats. The histogram of $10 \mathrm{~cm}$

277 elevation bins was generated using ArcGIS 10.2 (ESRI, Redlands, CA). While the 2012 LiDAR

278 DEM was collected shortly after the period of field sampling we consider this as a reasonable

279 estimate of vertical elevation within the delta for the time period of 2008 through 2011. Using

280 the areal estimates for $10 \mathrm{~cm}$ elevation bins based on the LiDAR DEM, the total mass of

281 sediment that was deposited in the deltaic wetlands at elevation $\geq-0.5 \mathrm{~m}$ NAVD88 was

282 estimated based on the total area of each $10 \mathrm{~cm}$ elevation range multiplied by the mean depth of 
283 sediment deposited from each spring flood within that range. This volume was multiplied by the

284 post-flood sediment bulk density estimated from the mean of 87 homogenized sediment cores

285 collected in July of 2009.

286 3. Results

287

\subsection{Seasonal net elevation change}

Analysis of the elevation change across all the measured plots indicated that all river

289 floods resulted in net elevation gain, with the largest net elevation change occurring in 2008 and

2902011 (Fig. 2). These years also exhibited similar river floods, with one main large discharge peak

291 and only a few smaller ancillary peaks. The spring river flood of 2009 had lower total discharge

292 and resulted in less net elevation gain than in 2008 or 2011, but was not significantly different

293 from 2011. In 2010 while positive elevation change was observed it was close to zero and the

294 pattern of river flood peaks was markedly different than other years, consisting of a sequence of

295 smaller peaks beginning in October 2009 and continuing through June 2010. The overlap of the

296 river flood with the season of winter cold front passage of 2009/10 resulted in a net elevation

297 change of close to zero for both these seasonal intervals (Fig. 2). A very different pattern was

298 observed in 2008/09 and 2010/11, when the cold front seasonal interval was distinct from the

299 river flood and resulted in net elevation loss in both years $(-2.2 \mathrm{~cm}$ and $-2.1 \mathrm{~cm}$, respectively).

300 Hurricane Gustav made landfall on the coast of Louisiana, passing $25 \mathrm{~km}$ to the northeast of

301 WLD on September 1 2008, and Hurricane Ike passed $275 \mathrm{~km}$ southwest of the delta on a

302 northwesterly track on September 12 2008, making landfall in Galveston, TX on September 13

$3032008,315 \mathrm{~km}$ from WLD (Fig. 1). Both hurricanes resulted in storm surges that affected the

304 study site (Fig. 2). Despite the much closer proximity of the eye, Hurricane Gustav resulted in a 
smaller surge with WLD water level $1.1 \mathrm{~m}$ above predicted as the storm surge came ashore,

(NOAA $8764227 \mathrm{Fig} .2$ ). The passage of the very large Hurricane Ike $275 \mathrm{~km}$ to the south of

WLD resulted in an increase in water level of $2.0 \mathrm{~m}$ above predicted, despite the storm

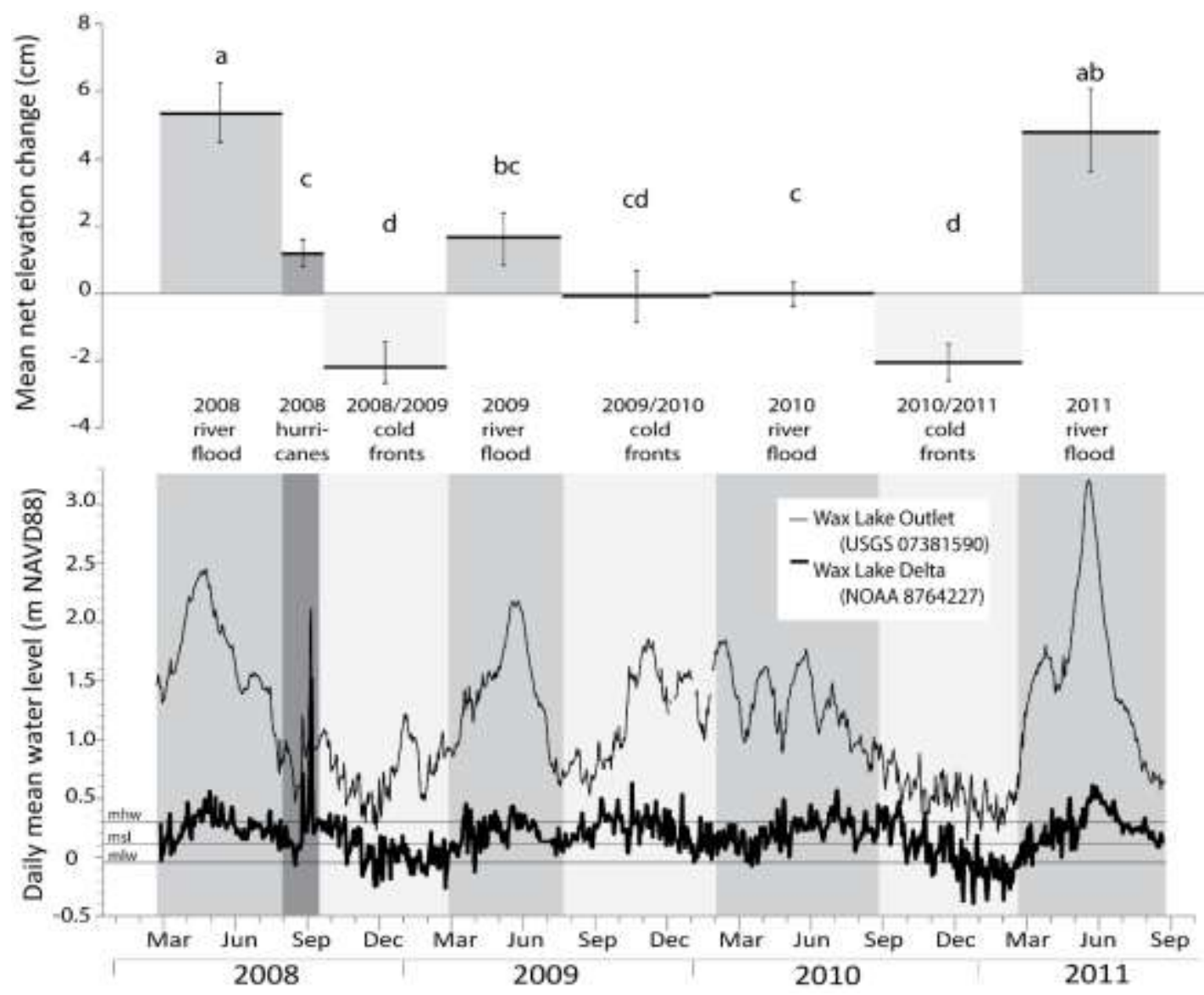

309

Figure 2. Mean \pm 1 standard error (SE) net elevation change $(\mathrm{cm})$ across all the measured plots for each seasonal interval with results of one-way ANOVA (Tukey's pairwise comparison significant differences at $\alpha=0.05$, indicated by letters). The spacing of bars is based on pre- and post-season sampling dates, which determined length of seasonal interval; see Table 1 for sampling dates and interval durations. Corresponding water levels reported relative to NAVD88, measured at Wax Lake Outlet gauge (USGS 07381590) shown with thin line and Amerada Pass gauge (NOAA 8764227) represented by thicker line. 
not making landfall in Louisiana (NOAA 8764227). These two hurricanes resulted in $1.2 \mathrm{~cm}$ net elevation gain, illustrating that hurricanes can deliver sediments, presumably resuspended from offshore, into coastal wetlands. The two storms resulted in about as much sediment elevation gain as a moderately large river flood (e.g. 2009). The passage of these two category 2 hurricanes occurred within a two-week time period, restricting our ability to sample between the storms. Therefore, the two hurricanes have been grouped into one seasonal interval. Estimating a return period for the hurricanes was therefore complicated by the probability of two storms in such a short period of time. The actual return period for two hurricanes within two weeks is likely much greater than the estimate for one hurricane in this area of the northern Gulf of Mexico of every 7 to $10 \mathrm{yr}$ (Keim et al. 2007). Due to the inability to sample the effect of each storm, we attributed half of the elevation gain to each hurricane to estimate long-term contributions. Based on the return period for one hurricane of 7 to $10 \mathrm{yr}$, we estimate that the net elevation gain that we observed from Hurricanes Gustav and Ike in 2008 of $1.2 \mathrm{~cm}$ would result in an annual contribution of 0.06 to $0.09 \mathrm{~cm} \mathrm{yr}^{-1}$.

We also investigated the differences in the depositional capacity of each seasonal forcing by comparing the mean of only elevation loss plots and only elevation gain plots separately for each season. Sampling plots with no change in elevation were not included in this analysis (Fig. 3). We found no significant difference in the mean of elevation loss plots from any seasonal forcing, indicating that the capacity to cause elevation loss either through sediment removal or compaction is consistent across all types of seasonal forcing and all years (Fig. 3). However significant differences were observed between the seasonal interval means of the elevation gain plots, with significantly higher elevation gain as a result of large river floods (Fig. 3). These results indicated that while all seasonal forcings result in comparable sediment elevation loss, the 
340 depositional capacity of the river floods and hurricanes occurs as a result of the availability of

341 suspended sediment brought in from outside of the system.

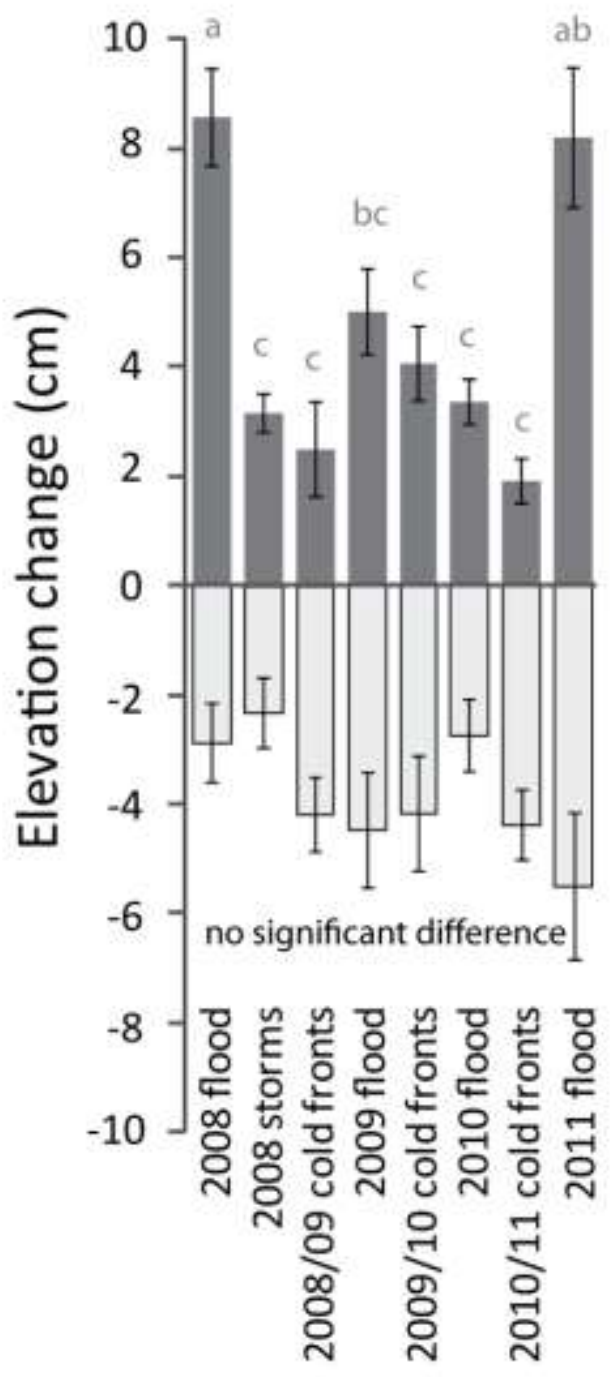

Mean \pm SE of only elevation gain plots, including ANOVA with Tukey's results

Mean \pm SE of only elevation loss plots, including ANOVA with Tukey's results 
344 Figure 3. Mean \pm 1 standard error $(\mathrm{SE})$ of only elevation gain $(\mathrm{cm})$ and elevation loss $(\mathrm{cm})$ for 345 each seasonal interval, including results of one-way ANOVA (Tukey's pairwise comparison 346 significant differences at $\alpha=0.05$, indicated by letters). There was no significant difference in 347 elevation loss plots. The differences between seasonal events are only seen in elevation gain 348 plots

\subsection{Discharge and sediment supply}

The total water discharge and total suspended sediment discharge are based on the

352 riverine sediment discharge rating curve (Eq. 1; Allison et al. 2012) and do not include the 353 suspended sediment load from offshore sediments that are likely resuspended and delivered to

354 the delta during hurricanes and possibly cold fronts, therefore underestimating the total sediment 355 delivery from these types of events (Fig. 4) The total WLO water and suspended sediment 356 discharge was higher during the 2008 river flood, with the 2011 river flood discharge just 357 slightly lower (Fig. 4). This likely accounted for the greater net mean elevation change observed 358 during the 2008 river flood compared to 2011 (Fig. 2). During the 2009/10 cold front seasonal

359 interval, which had the third highest water and total sediment discharge of all seasonal forcings 360 (Fig. 4), the mean net elevation change was close to zero (Fig. 2). This is due to the overlap of 361 the cold front seasonal interval with the multiple low discharge river flood peaks. (Fig. 2).

\section{Sediment surface elevation change across the deltaic island elevation gradient}

The largest net elevation change across the whole delta occurred as a result of river

364 floods in 2008 and 2011. In both years there was a clear trend in elevation gain relative to the 365 pre-season elevation gradient (Fig. 5). The direction of the trends differed from one another; in 3662008 there was more net deposition at lower elevations, with the peak at $-0.3 \mathrm{~m}$ NAVD88 and a 


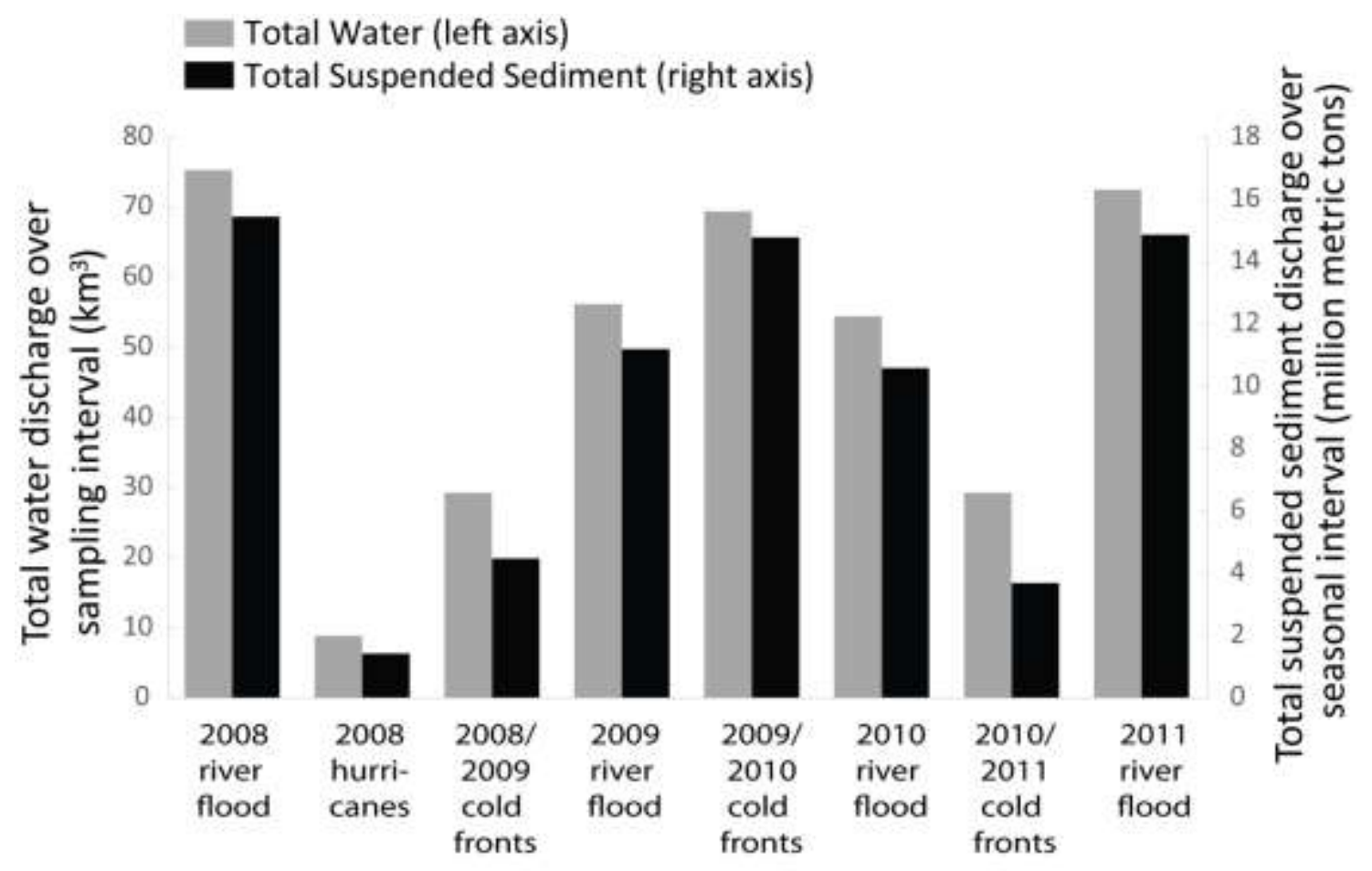

368 Figure 4. Total water discharge (cubic $\mathrm{km}$ ) on left axis and total suspended sediment discharge 369 (million metric tons) on right axis at Wax Lake Outlet for each seasonal interval.

371 gradual decline to $0.1 \mathrm{~m}$ NAVD88 (Fig. 5a). The opposite trend was observed in 2011, with little

372 or no net elevation gain at elevations $<0$ m NAVD88 and a gradual increase at higher elevations

373 with a peak at $0.3 \mathrm{~m}$ NAVD88 (Fig. 5d). The difference in the location of the net elevation gain

374 maxima between the 2008 and 2011 river floods may be due to the different patterns and

375 duration of flooding that occurred during each seasonal interval. In 2009 and 2010, when the

376 river flood discharge was lower, there were similar levels of net elevation gain across the whole

377 deltaic island top elevation gradient (Fig. 5b \& c). 
A. 2008 flood

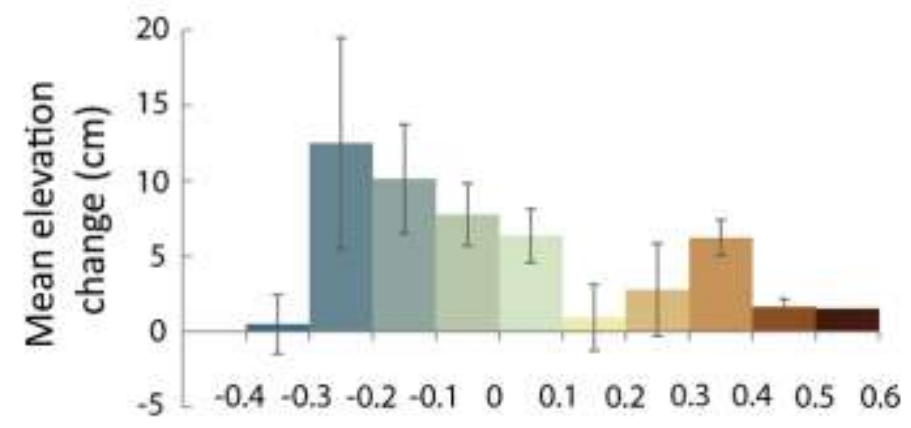

B. 2009 flood

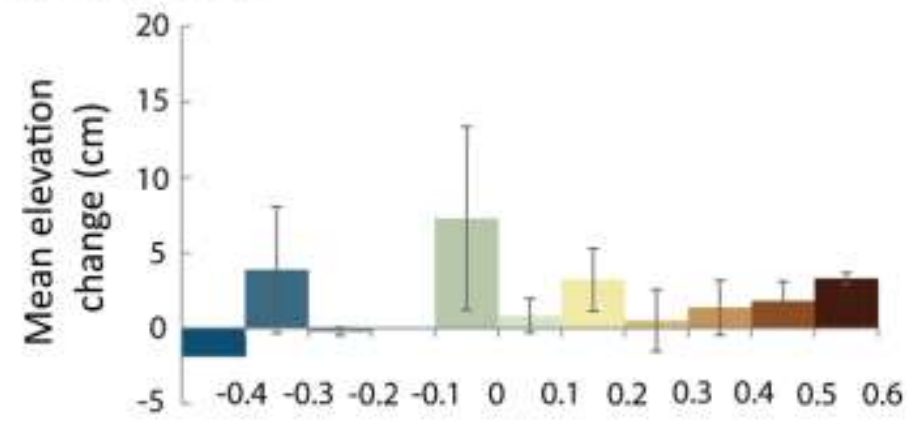

C. 2010 flood

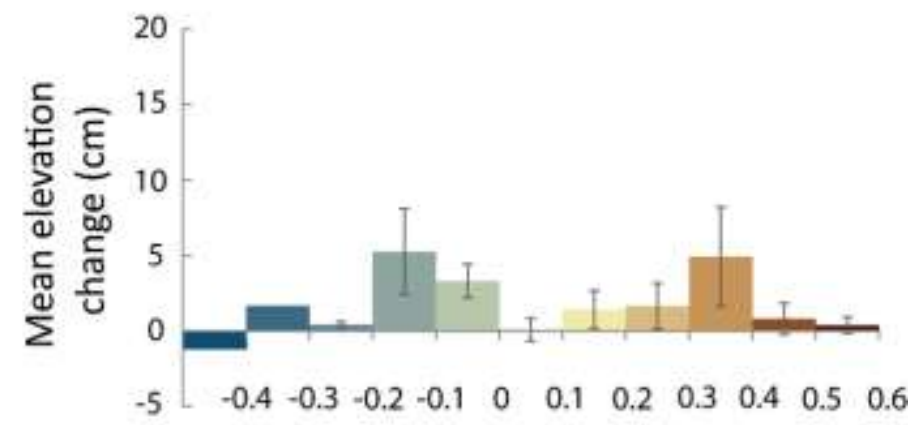

D. 2011 flood

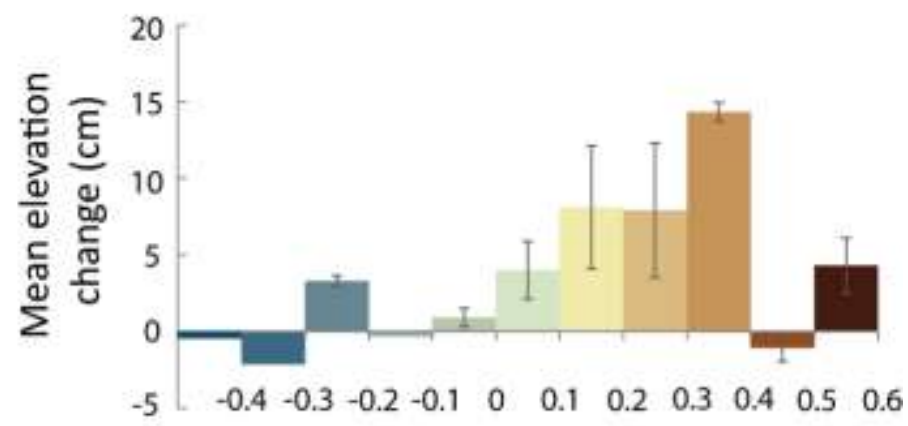

Pre-flood elevation (m NAVD88)

379 Figure 5. Mean \pm 1 standard error $(\mathrm{SE})$ net elevation change $(\mathrm{cm})$ within $10 \mathrm{~cm}$ elevation ranges 380 for all river flood seasonal intervals. Color of bars corresponds to $10 \mathrm{~cm}$ elevation ranges shown 381 on map of Wax Lake Delta in Fig. 1. 
(Fig. 6) illustrates that a larger portion of the deltaic wetlands ( $\geq-0.5 \mathrm{~m}$ NAVD88) occur at lower

384 elevations. During the 2008 flood, the highest elevation gain was seen at lower elevations,

385 resulting in much greater estimates of total sediment deposition than was observed from the 2011

386 river flood when the majority of elevation gain occurred at high elevations (Fig. 6). There was

387 an estimated 2,082,000 metric tons (T) deposited on deltaic wetlands in 2008, compared to of 824,000 $\mathrm{T}$ and 711,000 $\mathrm{T}$ respectively, much lower than the two large flood years (Table 3 ).

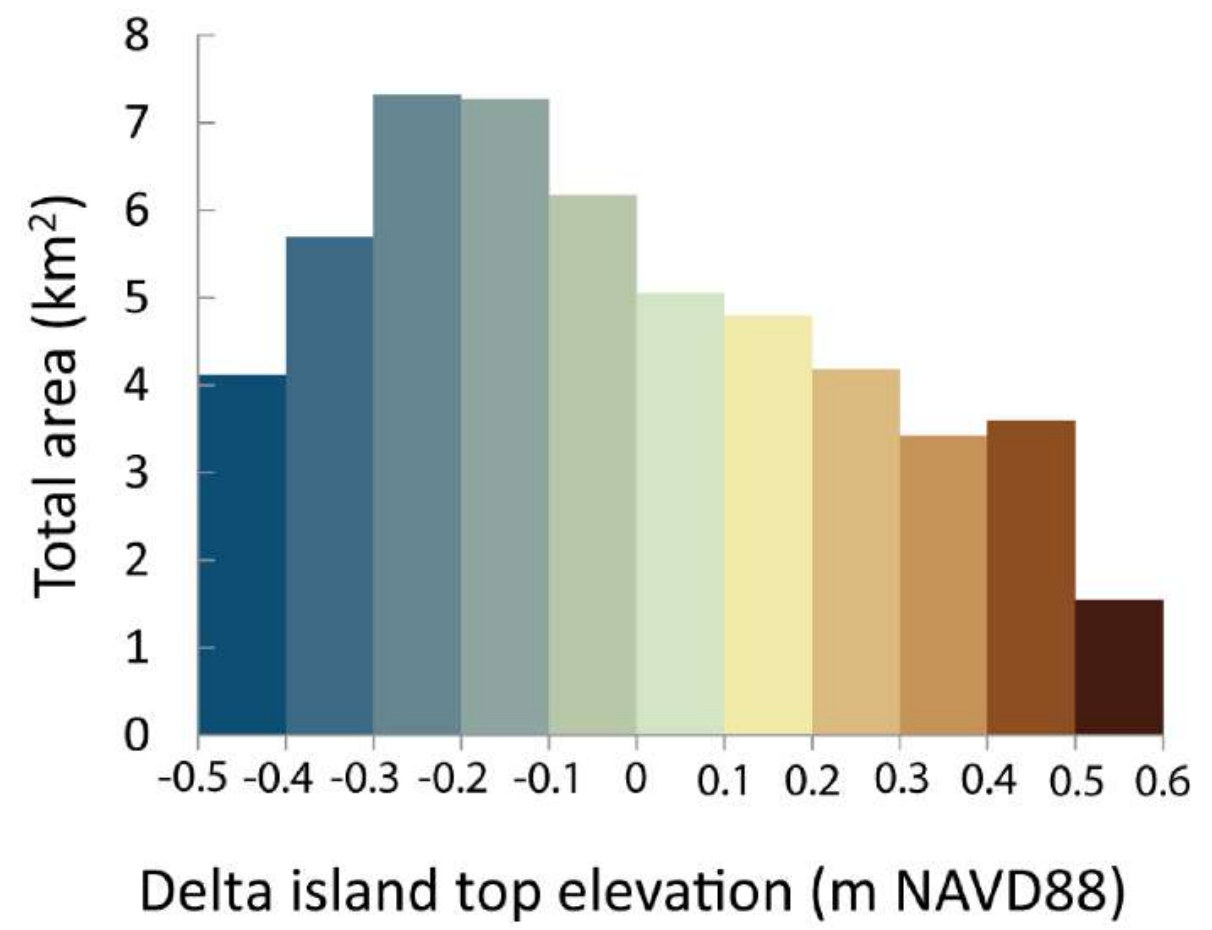


The sediment retention efficiency of the deltaic wetlands is estimated as the proportion of total suspended sediment discharge through WLO over the flood seasonal interval that was deposited on the deltaic wetlands at elevations greater than $-0.5 \mathrm{~m}$ NAVD88. The retention 399 efficiency during the 2008 river flood was higher than in any other year at $13.5 \%$, much higher 400 than the $7.6 \%$ retention efficiency from the 2011 river flood. The spring river flood seasonal 401 interval of 2009 and 2010 had $7.4 \%$ and 6.7\%, respectively (Fig. $7 \&$ Table 3). This analysis did 402 not include the trapping of sediment that likely occurred in the deeper portions of the delta $(<-0.5$

403 m NAVD88), which would increase the overall retention efficiency for the delta as a whole.

404 These results indicate that large floods with lower peak discharge but longer flood duration, as 405 was seen in 2008, maximize sediment retention efficiency and deltaic island top elevation gain.

406 The portion of the total suspended sediment discharge that is trapped and deposited in the deltaic 407 wetlands is critical for land building and the maintenance of the deltaic floodplain in response to 408 sea level rise and subsidence.

\section{Discussion}

\subsection{Estimates of deltaic sediment retention efficiency during spring river floods}

411 The greatest net elevation gain occurred during river flood intervals, compared to all other 412 seasonal forcings (Fig. 2), and is likely related to increased fluvial sediment delivery. The 413 amount of sediment delivered during river floods varied between years in relation to water 414 discharge (Fig. 7). We utilized the results of the field measurements to refine previous estimates 415 of sediment retention efficiency for WLD, reported as $23 \%$ by Törnqvist and others (2007), 416 which is double what we estimated for deltaic wetlands. However, their estimate was based on 417 retention for the whole delta topset, which includes both deltaic wetlands and deeper subaqueous 
418 channels, a total area of $104.6 \mathrm{~km}^{2}$, approximately double the deltaic wetland area at elevations 419 greater than or equal to $-0.5 \mathrm{~m}$ NAVD88 used in this study of $53.2 \mathrm{~km}^{2}$. Therefore if we scale 420 their original retention efficiency estimate of $23 \%$ to the smaller delta area used in this study 421 (limited to wetlands $\geq-0.5 \mathrm{~m}$ NAVD88) which amounted to $50.8 \%$ of their entire delta topset 422 area, the resulting $11.7 \%$ retention efficiency (Törnqvist et al. 2007) is very similar to our 423 estimate of 6.7 to $13.5 \%$. The large difference in sediment retention efficiency observed during 424 the 2008 compared to the 2011 river floods of $13.5 \%$ and $7.6 \%$, respectively, was surprising as 425 we personally observed many areas of large sandy deposits immediately after the 2011 flood. 426 However, based on our results it is likely these were restricted to higher elevations (Fig. 5d) and 427 less elevation gain occurred at lower elevations (Fig. 6). Analyses by Kolker et al. (2014) found 428 evidence of a shift in the location of the primary sediment depocenter, from nearshore deltaic 429 wetlands and the Atchafalaya Bay bottom, to the continental shelf during the 2011 flood, 430 postulating that the higher discharge of this large flood was able to move suspended sediments 431 further offshore. We observed a mean net elevation gain of $4.8 \mathrm{~cm}$ from the 2011 flood mainly in 432 higher elevation areas (Fig. 5d), while the 2008 river flood had higher mean net elevation gain $433(5.4 \mathrm{~cm})$ spread across a greater range of elevations and larger area (Fig. 5a). This coupled with 434 the observed increased elevation loss at lower elevations and bank collapse in 2011 (personal 435 observations and those of Shaw and Mohrig 2013) supports the shifting of the majority of 436 sediment deposition to locations further offshore. This is consistent with suggestion that the 437 extreme flooding event observed in 2011 was not an ideal model for deltaic restoration and 438 management in open bay environments (Kolker et al. 2014). If the goal is to increase sediment 439 delivery to nearshore deltaic wetlands, high total discharge floods, which extended over a longer 440 duration, as occurred in the 2008 spring flood, seem to better optimize water levels, sediment 
441 delivery and discharge, resulting in the greatest net elevation gain and retention on deltaic

442 wetlands. In doing these calculations we assume that the spatial and temporal coverage of our

443 dataset is adequate to do rough estimates; however we acknowledge that there are assumptions

444 inherent in these data specifically related to the small sampling size across the $10 \mathrm{~cm}$ elevation

445 bins. We contend that these estimates should be used as a basis for hypothesis development for

446 more robust experimental designs in order to better refine sediment retention estimates and the

447 overall sediment budget in the WLD.

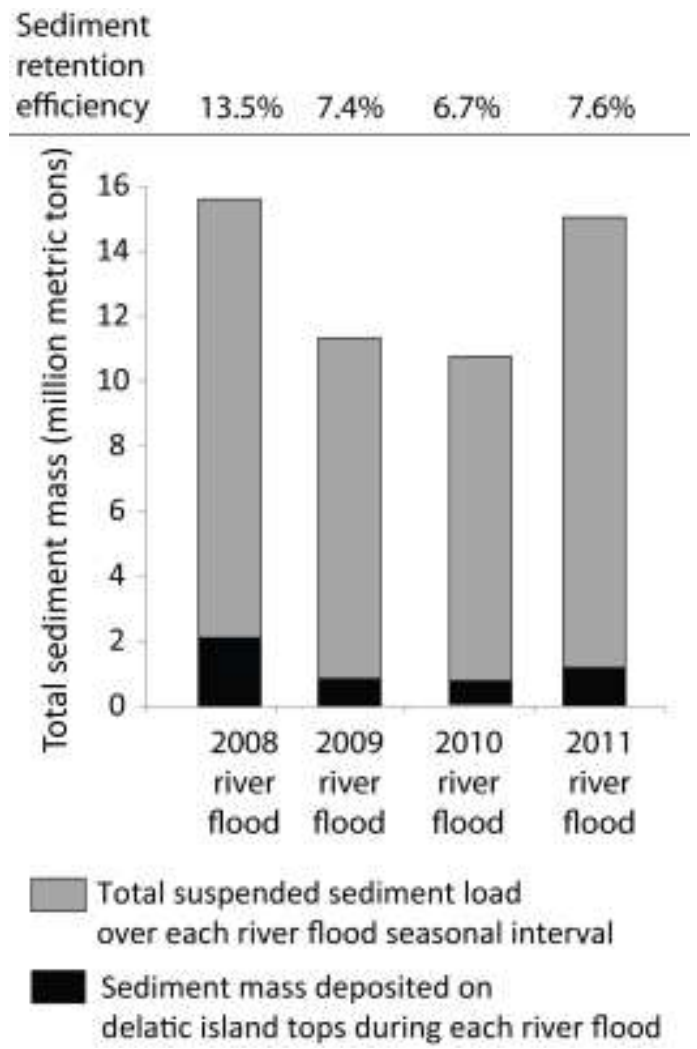

449 Figure 7. Total suspended sediment discharge (million metric tons) at Wax Lake Outlet over 450 each river flood seasonal interval and total mass of sediment deposited on deltaic island tops at 451 elevation $\geq-0.5 \mathrm{~m}$ NAVD88 during each seasonal interval. Retention efficiency for each river 452 flood seasonal interval is also shown. 
We measured a net elevation gain of $1.2 \pm 0.41 \mathrm{~cm}$ following the passage of Hurricanes

456 Gustav and Ike in September 2008. This is consistent with observations by other studies that

457 have shown that there is a resuspension of sediment which occurs as a result of the waves,

458 currents and storm surge associated with hurricane passage (Walker 2001). These sediments are

459 re-deposited as the surge moves inland into coastal wetlands, resulting in measurable elevation

460 gain attributed to hurricanes (Rejmánek et al. 1988; Guntenspergen et al. 1995; Nyman et al.

461 1995; Cahoon 2006; Turner et al. 2006; McKee and Cherry 2009; Morton and Barras 2011;

462 Tweel and Turner 2012). Recent studies have measured deposition rates resulting from

463 hurricanes (Turner et al. 2006; Tweel and Turner 2012). While both of these studies adequately

464 measure sediment deposition, they fail to also quantify erosion, essentially reporting gross

465 deposition. These gross deposition rates are then used to interpolate to a landscape scale the

466 amount of hurricane derive sediment accumulation across the northern Gulf of Mexico coastal

467 zone. We contend that by using only a measure of deposition (i.e. positive elevation change) the

468 landscape scale values reported in these studies are overestimates the total sediment attributable

469 to hurricanes along the Northern Gulf of Mexico coast (Turner et al. 2006; Tweel and Turner

470 2012). In order to accurately interpolate their deposition estimates as they did over thousands of

471 square $\mathrm{km}$ of coastal wetlands and open water, they would need to include a factor that

472 represents the erosional component resulting from the hurricanes as well. Our analysis provides

473 an estimate of this erosional component. Of the 85 plots measured in replicate after the passage

474 of Hurricanes Gustav and Ike, 53 exhibited a mean deposition of $3.14 \pm 0.36 \mathrm{~cm}, 27$ exhibited

475 elevation loss with a mean of $-2.35 \pm 0.64 \mathrm{~cm}$ and 5 exhibited no change in elevation. The

476 estimate of gross elevation gain $(3.14 \pm 0.36 \mathrm{~cm})$ is 2.6 times larger than the final estimate of net 
477 elevation gain $(1.21 \pm 0.41 \mathrm{~cm})$. Therefore, we suggest that the overestimates reported for the 478 contribution of hurricanes sediments across the coastal zone reported in Turner et al. 2006, and 479 Tweel and Turner 2012, should be adjusted downward by including an erosional component 480 factor of 0.385 in order to get a more accurate representation of net sediment accumulation 481 resulting from hurricanes across the northern Gulf of Mexico Coastal zone. While this is still an 482 appreciable sediment subsidy for coastal wetlands, especially in abandoned delta lobes that 483 receive very little riverine sediment input (McKee and Cherry 2009; Baustian and Mendelssohn 484 2015), it is only a small contribution in wetlands that receive appreciable riverine sediment 485 delivery (Törnqvist et al. 2007). 
Table 3.Total surface area for delta island top $10 \mathrm{~cm}$ elevation ranges $\geq-0.5 \mathrm{~m}$ NAVD88, estimate of volume of sediment deposited over each river flood seasonal interval, and total suspended sediment (TSS) discharge from Wax Lake Outlet over each river flood interval. Retention efficiency is determined as the proportion of TSS discharge that is retained on delta island tops. Estimates of sediment mass are based on a mean post river flood bulk density of $0.86 \pm 0.02 \mathrm{~g} / \mathrm{cm}^{3}$ from $10 \mathrm{~cm}$ deep sediment cores collected following 2009 spring river flood.

2008 Flood

2009 flood

2010 Flood

2011 flood

\begin{tabular}{|c|c|c|c|c|c|c|c|c|c|}
\hline & & 2008 Flood & & 2009 flood & & 2010 Floo & & 2011 flood & \\
\hline $\begin{array}{l}\text { Elevation ranges } \\
\text { (m NAVD88) }\end{array}$ & $\begin{array}{c}\text { Total } \\
\text { surface } \\
\text { area }\left(\mathrm{km}^{2}\right)\end{array}$ & $\begin{array}{c}\text { Mean } \\
\text { sediment } \\
\text { elevation } \\
\text { change }(\mathrm{cm})\end{array}$ & $\begin{array}{l}\text { Estimate } \\
\text { of mass of } \\
\text { sediment } \\
\text { (metric } \\
\text { tons) } \\
\text { based on mean } \\
\text { bulk density of } \\
0.71 \mathrm{~g} / \mathrm{cm}^{3}\end{array}$ & $\begin{array}{l}\text { Mean } \\
\text { sediment } \\
\text { elevation } \\
\text { change } \\
(\mathrm{cm})\end{array}$ & $\begin{array}{c}\text { Estimate } \\
\text { of mass of } \\
\text { sediment } \\
\text { (metric } \\
\text { tons) } \\
\text { based on mean } \\
\text { bulk density of } \\
0.86 \mathrm{~g} / \mathrm{cm} 3\end{array}$ & $\begin{array}{l}\text { Mean } \\
\text { sediment } \\
\text { elevation } \\
\text { change } \\
(\mathrm{cm})\end{array}$ & $\begin{array}{l}\text { Estimate } \\
\text { of mass of } \\
\text { sediment } \\
\text { (metric } \\
\text { tons) } \\
\text { based on mean } \\
\text { bulk density of } \\
0.71 \mathrm{~g} / \mathrm{cm}^{3}\end{array}$ & $\begin{array}{l}\text { Mean } \\
\text { sediment } \\
\text { elevation } \\
\text { change } \\
(\mathrm{cm})\end{array}$ & $\begin{array}{l}\text { Estimate of } \\
\text { mass of } \\
\text { sediment } \\
\text { (metric } \\
\text { tons) } \\
\text { based on mean } \\
\text { bulk density of } \\
0.72 \mathrm{~g} / \mathrm{cm}^{3}\end{array}$ \\
\hline-0.50 to -0.41 & 4.11 & -- & -- & -1.8 & $-64,000$ & -1.1 & $-32,000$ & -0.5 & -15000 \\
\hline-0.40 to -0.31 & 5.69 & $0.5 \pm 2.0$ & 20,000 & $3.9 \pm 4.2$ & 190,000 & 1.7 & 69,000 & -2.1 & -86000 \\
\hline-0.30 to -0.21 & 7.32 & $12.5 \pm 7.0$ & 650,000 & $-0.2 \pm 0.3$ & $-13,000$ & $0.4 \pm 0.2$ & 21,000 & $3.3 \pm 0.4$ & 170000 \\
\hline-0.20 to -0.11 & 7.27 & $10.1 \pm 3.6$ & 520,000 & -- & -- & $5.3 \pm 2.8$ & 270,000 & -0.3 & -16000 \\
\hline-0.10 to -0.01 & 6.17 & $7.8 \pm 2.1$ & 340,000 & $7.3 \pm 6.1$ & 390,000 & $3.3 \pm 1.1$ & 140,000 & $0.9 \pm 0.6$ & 40000 \\
\hline 0.0 to 0.09 & 5.05 & $6.4 \pm 1.8$ & 230,000 & $0.8 \pm 1.1$ & 35,000 & $0.1 \pm 0.7$ & 3,600 & $4.0 \pm 1.9$ & 150000 \\
\hline 0.10 to 0.19 & 4.8 & $0.9 \pm 2.2$ & 31,000 & $3.2 \pm 2.1$ & 130,000 & $1.4 \pm 1.2$ & 48,000 & $8.1 \pm 4$ & 280000 \\
\hline 0.20 to 0.29 & 4.18 & $2.8 \pm 3.1$ & 83,000 & $0.5 \pm 2.1$ & 18,000 & $1.6 \pm 1.5$ & 47,000 & $7.9 \pm 4.4$ & 240000 \\
\hline 0.30 to 0.39 & 3.42 & $6.2 \pm 1.2$ & 150,000 & $1.3 \pm 1.8$ & 38,000 & $4.9 \pm 3.2$ & 120,000 & $\begin{array}{l}14.3 \\
\pm 0.6\end{array}$ & 350000 \\
\hline 0.40 to 0.49 & 3.59 & $1.6 \pm 0.5$ & 41,000 & $1.8 \pm 1.3$ & 56,000 & $0.8 \pm 1.0$ & 20,000 & $-1.1 \pm 0.9$ & -28000 \\
\hline$>0.50 \mathrm{~m}$ & 1.55 & 1.5 & 17,000 & $3.3 \pm 0.4$ & 44,000 & $0.4 \pm 0.5$ & 4,400 & $4.3 \pm 1.8$ & 48000 \\
\hline Total surface area & 53.2 & & & & & & & & \\
\hline $\begin{array}{l}\text { Total mass of sedir } \\
(\geq-0.5 \mathrm{~m} \text { NAVD } 88\end{array}$ & $\begin{array}{l}\text { it deposite } \\
\text { y flood (m }\end{array}$ & $\begin{array}{l}\text { island tops } \\
\text { t tons) }\end{array}$ & $2,082,000$ & & 824,000 & & 711,000 & & $1,133,000$ \\
\hline $\begin{array}{l}\text { Percentage of total } \\
\text { discharge over seas }\end{array}$ & $\begin{array}{l}\text { uspended sed } \\
\text { nal interval }\end{array}$ & & $13.5 \%$ & & $7.4 \%$ & & $6.7 \%$ & & $7.6 \%$ \\
\hline
\end{tabular}


Here we use the synoptic results obtained from the passage of Hurricanes Gustav and Ike 493 to estimate the long-term contribution of hurricanes to sediment elevation gain in the WLD, 494 particularly relative to large river floods. While the reported return period for hurricanes $(\geq$ 495 category 1) along the MRD is one every 7-10 years (Keim et al. 2007), the hurricane passage that 496 occurred during this study is unusual in that it included the passage of two category 2 storms 497 within two weeks. From an ecological and sediment transport perspective it is likely that 498 Hurricane Ike, with its larger shifts in water level, had a much greater effect on the ecology and 499 geomorphology of deltaic wetlands. However this cannot be determined from our data because 500 no sampling occurred during the time between the two storms. We estimate that the net elevation 501 gain that we observed from Hurricanes Gustav and Ike in 2008 of $1.21 \mathrm{~cm}$ would result in an 502 annual contribution of 0.06 to $0.09 \mathrm{~cm} \mathrm{yr}^{-1}$. This long-term estimate is much lower than the 503 vertical accretion rate of 1.4 to $2 \mathrm{~cm} \mathrm{yr}^{-1}$ estimated from ${ }^{137} \mathrm{Cs}$ peaks in nearby wetland and bay 504 bottoms that are also receiving riverine mineral sediment inflow (DeLaune et al. 1987; Mossa 505 and Roberts 1990). The return period for large river floods equal or greater in water level than 506 the 2008 flood is once every $12 \mathrm{yr}$ based on the entire record of the Atchafalaya River at 507 Simmesport LA (USGS 07381490) which extends from 1932 to 2015. Using this estimated 508 return period and a mean net deposition of $5.4 \mathrm{~cm}$ and $4.9 \mathrm{~cm}$ in 2008 and 2011, respectively, the 509 long-term estimate of mineral sediment contribution from large river floods is 0.42 to $0.46{\mathrm{~cm} \mathrm{yr}^{-}}^{-}$

5101 . Direct comparison of the long-term sediment elevation gain from large floods and hurricanes 511 shows that long-term hurricane derived contribution to delta wetland elevation gain is less than $51222 \%$ of that from large river floods. 
The net loss of elevation resulting from annual cold front passage can effectively cancel

515 out flood elevation gain except in large river flood years, which occur about once every $12 \mathrm{yr}$.

516 There is little variability in number and pattern of cold front occurrence from year to year (Hardy

517 and Henderson 2003). Therefore the effects of cold fronts on elevation loss are occurring to the

518 same degree every year. This pattern of elevation loss, due to cold front seasonal forcings in the

519 WLD and Atchafalaya Delta has been reported in a number of other studies (Rouse et al. 1978;

520 Kemp et al. 1980; Roberts and Adams 1980; Mossa and Roberts 1990). This has important

521 implications for land building capacity of this type of system as the need to offset this annual

522 elevation loss is critical for continual net elevation gain. While cold front elevation loss is

523 significant within the wetlands within the WLD itself, it has been reported that resuspended

524 sediments from cold front passage as well as river floods have resulted in appreciable sediment

525 deposition along tidal creeks in nearby organic headland marshes, brackish marshes along

526 Fourleague Bay and near shore bay bottoms (DeLaune et al. 1987; Perez et al. 2000; Roberts et

527 al. 2015). Transport of suspended sediment via cold front water level fluctuations in areas that do

528 not receive direct river inflow has also been shown, such as salt marshes in sediment limited

529 Terrebone Basins (Reed 1989). Also, cold front resuspension and transport of sediments

530 westward from the Atchafalaya Bay via longshore current results in accretion of mudflats in the

531 Louisiana Chenier Plain (Roberts et al. 1989; Mossa and Roberts 1990; Kineke et al. 2006).

532 Therefore fluvial sediments initially deposited on the deltaic wetlands of WLD during river

533 floods may act as a sediment source during winter cold front resuspension events and support

534 secondary sediment transport to far field wetlands throughout the coastal zone. 
While two large river floods (2008 and 2011) occurred within only four years during our sampling, the return period of river floods this size is historically one every 12 years. The large river floods resulted in net annual elevation gain. The moderate and smaller river floods, like 2009 and 2010, seem to be offset on an annual basis by cold front elevation loss, resulting in no net change in elevation across the delta for the year (Fig. 2). This pattern of vertical elevation gain in which there is no net growth of deltaic island elevation for a number of years (with small to moderate river floods), punctuated by net elevation gain from periodic large river floods (approximately once every $12 \mathrm{yr}$ ), may be important for understanding previous long term estimates of vertical delta growth and predicting future elevation gain. Previous delta land building predictions for both the WLD and Atchafalaya Deltas have been over-estimated with some researchers predicting that both deltas would merge and fill the Atchafalaya Bay within the early part of the $21^{\text {st }}$ century (Shlemon 1975; Roberts and Adams 1980; van Heerden et al. 1983;

DeLaune et al. 1987; Majersky et al. 1997). This may be due to the lack of inclusion of elevation loss resulting from cold fronts in these predictive models. It is likely that numerical models currently used for restoration planning that do not take cold front removal into account will also overestimate land building rates (Parker and Sequeiros 2006; Hanegan 2011). Inclusion of this net degradational process in future delta models is critical for accurate prediction of delta morphodynamics and development.

\section{Conclusions and implications for coastal restoration}

Coastal Louisiana is an area where dynamic marine and riverine forces shape deltaic landforms. This study in an actively prograding delta allows us to better understand the relative contributions of three major forcings, river floods, cold fronts and hurricanes to delta growth. 
557 River floods are the main drivers of elevation gain in the WLD, with the highest discharge floods

558 resulting in significantly more elevation gain than lower discharge floods; however without the

559 combined elevation gain attributed to both large and small floods, net positive elevation gain

560 would not be possible over the long-term, due to consistent annual loss in elevation due to cold

561 fronts. We also found that while hurricanes do deliver a net elevation gain to the deltaic

562 floodplain wetlands, they also result in appreciable elevation loss, equal to $39 \%$ of the gross

563 elevation gain. This is an important consideration that is often left out of other studies of

564 hurricane sediment subsidy. The long-term annual contribution of hurricane derived sediments to

565 these deltaic wetlands based on a return period of one every 7-10 years is less than $22 \%$ of the

566 sediment delivered by large river floods in the WLD. River diversions designed for suspended

567 sediment delivery have been proposed as a potential means to offset wetland loss in coastal

568 Louisiana (CPRA 2012). We conclude that in locations that experience similar hydrological

569 forcings to the WLD, the operation of these diversions would need to be designed with these

570 findings in mind. It is also crucial to include cold front elevation loss in numerical models of

571 delta building to accurately predict future land building.

\section{Acknowledgements}

573 This work was supported by the National Science Foundation via the National Center for Earth-

574 Surface Dynamics [EAR-0120914], Frontiers of Earth Surface Dynamics [OCE-1135427], and

575 the Coastal SEES program at LSU [EAR-1427389]. Funding for field logistics was also provided

576 by U.S. Shell. The authors would like to thank two reviewers for their thoughtful suggestions

577 which improved the manuscript greatly, as well as Edward Castañeda for assistance in field

578 program management. 
Allen, Y.C., Couvillion, B.R., Barras, J.A., 2011. Using multitemporal remote sensing imagery and inundation measures to improve land change estimates in coastal wetlands. Estuaries and Coasts 35, 190-200. doi:10.1007/s12237-011-9437-z

Allison, M.A., Kineke, G.C., Gordon, E.S., Goi, M., 2000. Development and reworking of a seasonal flood deposit on the inner continental shelf off the Atchafalaya River. Cont. Shelf Res. 20, 2267-2294. doi:10.1016/S0278-4343(00)00070-4

Allison, M.A., Meselhe, E.A., 2010. The use of large water and sediment diversions in the lower Mississippi River (Louisiana) for coastal restoration. J. Hydrol. 387, 346-360. doi:10.1016/j.jhydrol.2010.04.001

Allison, M., Demas, C.R., Ebersole, B., Kleiss, B., Little, C.D., Meselhe, E., Powell, N.J., Pratt, T.C., Vosburg, B.M., 2012. A water and sediment budget for the lower MississippiAtchafalaya River in flood years 2008-2010: Implications for sediment discharge to the oceans and coastal restoration in Louisiana. J. Hydrol. 432-433, 84-97. doi:10.1016/j.jhydrol.2012.02.020

Baumann, R.H., Day, J.W., Miller, C.A., 1984. Mississippi deltaic wetland survival: sedimentation versus coastal submergence. Science (80-. ). 224, 1093-1095. doi:10.1126/science.224.4653.1093

Baustian, J.J., Mendelssohn, I., 2015. Hurricane-induced sedimentation Improves marsh resilience and vegetation vigor under high rates of relative sea level rise. Wetlands 35, 795802. doi:10.1007/s13157-015-0670-2

Bevington, A. E., 2016. Dynamics of land building and ecological succession in a prograding deltaic floodplain, Wax Lake Delta, LA, USA. Louisiana State University.

Cahoon, D.R., 2006. A review of major storm impacts on coastal wetland elevations. Estuaries and Coasts 29, 889-898. doi:10.1007/BF02798648

Coastal Protection and Restoration Authority (CPRA). 2012. Louisiana's Comprehensive Master Plan for a Sustainable Coast -2012. Baton Rouge, Louisiana.

Day, J.W., Boesch, D.F., Clairain, E.J., Kemp, G.P., Laska, S.B., Mitsch, W.J., Orth, K., Mashriqui, H., Reed, D.J., Shabman, L., Simenstad, C. a, Streever, B.J., Twilley, R.R., Watson, C.C., Wells, J.T., Whigham, D.F., 2007. Restoration of the Mississippi Delta: lessons from Hurricanes Katrina and Rita. Science (80-. ). 315, 1679-1684. doi: $10.1126 /$ science. 1137030

Day, J.W., Christian, R.R., Boesch, D.M., Yáñez-Arancibia, A., Morris, J., Twilley, R.R., Naylor, L., Schaffner, L., Stevenson, C., 2008. Consequences of climate change on the 
ecogeomorphology of coastal wetlands. Estuaries and Coasts 31, 477-491. doi:10.1007/s12237-008-9047-6

DeLaune, R.D., Smith, C.J., Patrick, W.H., Roberts, H.H., 1987. Rejuvenated marsh and baybottom accretion on the rapidly subsiding coastal plain of U.S. Gulf coast: a second-order effect of the emerging Atchafalaya delta. Estuar. Coast. Shelf Sci. 25, 381-389. doi:10.1016/0272-7714(87)90032-1

Dietrich, J.C., Westerink, J.J., Kennedy, A.B., Smith, J.M., Jensen, R.E., Zijlema, M., Holthuijsen, L.H., Dawson, C., Luettich, R.A., Powell, M.D., Cardone, V.J., Cox, A.T., Stone, G.W., Pourtaheri, H., Hope, M.E., Tanaka, S., Westerink, L.G., Westerink, H.J., Cobell, Z., 2011. Hurricane Gustav. 2008. Waves and storm surge: hindcast, synoptic analysis, and validation in Southern Louisiana. Mon. Weather Rev. 139, 2488-2522. doi:10.1175/2011MWR3611.1

Draut, A.E., Kineke, G.C., Huh, O.K., Grymes, J.M., Westphal, K.A., Moeller, C.C., 2005. Coastal mudflat accretion under energetic conditions, Louisiana chenier-plain coast, USA. Mar. Geol. 214, 27-47. doi:10.1016/j.margeo.2004.10.033

Ericson, J.P., Vörösmarty, C.J., Dingman, S.L., Ward, L.G., Meybeck, M., 2006. Effective sealevel rise and deltas: Causes of change and human dimension implications. Glob. Planet. Change 50, 63-82. doi:10.1016/j.gloplacha.2005.07.004

Fagherazzi, S., Edmonds, D.A., Nardin, W., Leonardi, N., Canestrelli, A., Falcini, F., Jerolmack, D.J., Mariotti, G., Rowland, J.C., Slingerland, R.L., 2015. Dynamics of river mouth deposits. Rev. Geophys. 53, 1-31. doi:10.1029/88EO01108

Feng, Z., Li, C., 2010. Cold-front-induced flushing of the Louisiana Bays. J. Mar. Syst. 82, 252264. doi:10.1016/j.jmarsys.2010.05.015

Georgiou, I.Y., FitzGerald, D.M., Stone, G.W., 2005. The impact of physical processes along the Louisiana Coast. J. Coast. Res. Sp. Issue, 72-89.

Guntenspergen, G.R., Cahoon, D.R., Grace, J., Steyer, G.D., Fournet, S., Townson, M.A., Foote, A.L., 1995. Disturbance and recovery of the Louisiana coastal marsh landscape from the impacts of Hurricane Andrew. J. Coast. Res. Sp. Issue, 324-339.

Hanegan, K.C.., 2011. Modeling the evolution of the Wax Lake Delta in Atchafalaya Bay, Louisiana. Louisiana State University.

Hardy, J., Henderson, K., 2003. Cold front variability in the Southern United States and the influence of atmospheric teleconnection patterns. Phys. Geogr. 24, 120-137. doi:10.2747/0272-3646.24.2.120

Holm, G.O., Sasser, C.E., 2001. Differential salinity response between two Mississippi River Subdeltas: implications for changes in plant composition. Estuaries 24, 78. 
649

650

651

652

653

654

655

656

657

658

659

660

661

662

663

664

665

666

667

668

669

670

671

672

673

674

675

676

677

678

679

680

Irish, J.L., Resio, D.T., 2010. A hydrodynamics-based surge scale for hurricanes. Ocean Eng. 37 , 69-81. doi:10.1016/j.oceaneng.2009.07.012

Johnson, W.B., Sasser, C.E., Gosselink, J.G., 1985. Succession of vegetation in an evolving river delta, Atchafalaya Bay, Louisiana. J. Ecol. 73, 973-986. doi:10.2307/2260162

Keim, B.D., Muller, R.A., Stone, G.W., 2007. Spatiotemporal patterns and return periods of tropical storm and hurricane strikes from Texas to Maine. J. Clim. 20, 3498-3509.

Kemp, G.P., Wells, J.T., van Heerden, I.L., 1980. Frontal passages affect delta development in Louisiana. Coast. Oceanogr. Climatol. News 3, 4-5.

Kim, W., Mohrig, D., Twilley, R., Paola, C., Parker, G., 2009. Is It Feasible to Build New Land in the Mississippi River Delta? Eos, Trans. Am. Geophys. Union 90, 373-374. doi:10.1029/2009EO420001

Kineke, G.C., Higgins, E.E., Hart, K., Velasco, D., 2006. Fine-sediment transport associated with cold-front passages on the shallow shelf, Gulf of Mexico. Cont. Shelf Res. 26, 20732091. doi:10.1016/j.csr.2006.07.023

Kolker, A.S., Li, C., Walker, N.D., Pilley, C., Ameen, A.D., Boxer, G., Ramatchandirane, C., Ullah, M., Williams, K.A., 2014. The impacts of the great Mississippi/Atchafalaya River flood on the oceanography of the Atchafalaya Shelf. Cont. Shelf Res. 86, 17-33. doi:10.1016/j.csr.2014.04.023

Li, C., Roberts, H., Stone, G.W., Weeks, E., Luo, Y., 2011. Wind surge and saltwater intrusion in Atchafalaya bay during onshore winds prior to cold front passage. Hydrobiologia 658, 27-39. doi:10.1007/s10750-010-0467-5

Majersky, S., Roberts, H.H., Cunningham, R., Kemp, G.P., Chacko, J.J., 1997. Facies development in the Wax Lake Outlet Delta:Present and future trends. Basin Res. Inst. Bull. 7, 50-66.

McKee, K.L., Cherry, J.A., 2009. Hurricane Katrina sediment slowed elevation loss in subsiding brackish marshes of the Mississippi River delta. Wetlands 29, 2-15. doi:10.1672/08-32.1

Moeller, C.C., Huh, O.K., Roberts, H.H., Gumley, L.E., Menzel, W.P., 2012. Response of Louisiana Coastal Environments to a Cold Front Passage. J. Coast. Res.

Morton, R.A., Barras, J.A., 2011. Hurricane Impacts on Coastal Wetlands: A Half-Century Record of Storm-Generated Features from Southern Louisiana. J. Coast. Res. 275, 27-43. doi:10.2112/JCOASTRES-D-10-00185.1

Mossa, J., Roberts, H.H., 1990. Synergism of riverine and winter storm related sediment 
transport processes in Lousiana coastal wetlands. Trans. Coast Assoc. Geol. Soc. 40, 635642.

Nardin, W., Edmonds, D.A., 2014. Optimum vegetation height and density for inorganic sedimentation in deltaic marshes 7, 1-5. doi:10.1038/NGEO2233

Neill, C.F., Allison, M. a., 2005. Subaqueous deltaic formation on the Atchafalaya Shelf, Louisiana. Mar. Geol. 214, 411-430. doi:10.1016/j.margeo.2004.11.002

Nyman, J.A., Crozier, C.R., DeLaune, R.D., 1995. Roles and patterns of hurricane sedimentation in an estuarine marsh landscape. Estuar. Coast. Shelf Sci. 40, 665-679. doi:10.1006/ecss.1995.0045

Panin, N., Jipa, D., 1997. Danube River Sediment Input and its Interaction with the NorthWestern Black Sea. Cont. Margins Sea Lev. Chang. 54, 551-562. doi:10.1006/ecss.2000.0664

Paola, C., Twilley, R.R., Edmonds, D.A., Kim, W., Mohrig, D., Parker, G., Viparelli, E., Voller, V.R., 2011. Natural Processes in Delta Restoration : Application to the Mississippi Delta. Ann. Rev. Mar. Sci. 3, 67-91. doi:10.1146/annurev-marine-120709-142856

Parker, B., Milbert, D., Hess, K., Gill, S., 2003. National vertical datum transformation database. Proc. from US hydro 2003 Conf. 24-27.

Parker, G., Sequeiros, O.E., 2006. Large Scale River Morphodynamics: Application to the Mississippi Delta. Proceedings, River Flow 2006 Conf. 3-11.

Perez, B.C., Day, J.W., Rouse, L.J., Shaw, R.F., Wang, M., 2000. Influence of Atchafalaya River Discharge and Winter Frontal Passage on Suspended Sediment Concentration and Flux in Fourleague Bay, Louisiana. Estuar. Coast. Shelf Sci. 50, 271-290. doi:10.1006/ecss.1999.0564

Powell, M.D., Reinhold, T.A., 2007. Tropical cyclone destructive potential by integrated kinetic energy. Bull. Am. Meteorol. Soc. 88, 513-526. doi:10.1175/BAMS-88-4-513

Pugh, D.T., 1996. Tides, surges and mean sea-level: a handbook for engineers and scientists, 2nd ed. Chichester : Wiley. doi:10.1016/0264-8172(88)90013-X

Reed, D., 1989. Patterns of sediment deposition in subsiding coastal salt marshes, Terrebonne Bay, Louisiana: The role of winter storms. Estuaries 12, 222-227.

Rejmánek, M., Sasser, C.E., Peterson, G.W., 1988. Hurricane-induced sediment deposition in a gulf coast marsh. Estuar. Coast. Shelf Sci. 27, 217-222. doi:10.1016/0272-7714(88)90091-1

Roberts, H.H., Adams, R.D., 1980. Evolution of sand-dominant subaerial phase, Atchafalaya Delta, Louisiana. Am. Assoc. Pet. Geol. Bull. 64, 264-279. doi:10.1306/2F918964-16CE- 
715

716

717

718

719

720

721

722

723

724

725

726

727

728

729

730

731

732

733

734

735

736

737

738

739

740

741

742

743

744

745

746

Roberts, H.H., DeLaune, R.D., White, J.R., Li, C., Sasser, C.E., Braud, D., Weeks, E., Khalil, S., 2015. Floods and cold front passages: impacts on coastal marshes in a river diversion setting (Wax Lake Delta Area, Louisiana). J. Coast. Res. 31, 1057 - 1068. doi:10.2112/JCOASTRES-D-14-00173.1

Roberts, H.H., Huh, O.K., Hsu, S.A., Rouse Jr., J.L., Rickman, D.A., 1989. Winter storm impacts on the chenier plain coast of southwestern Louisiana. Trans. Gulf Coast Assoc. Geol. Soc. 39, 515-522.

Roberts, H.H., Walker, N.D., Sheremet, A., Stone, G.W., Haq, B.U., 2005. Effects of cold fronts on bayhead delta development: Atchafalaya Bay, Louisiana, USA. High Resolut. Morphodynamics Sediment. Evol. Estuaries 8, 269-298. doi:10.1007/1-4020-3296-x_13

Rouse, L.J., Roberts, H.H., Cunningham, R.H.W., 1978. Satellite observation of the subaerial growth of the Atchafalaya Delta, Louisiana. Geology 6, 405-408. doi:10.1130/00917613(1978)6<405:SOOTSG>2.0.CO;2

Shaffer, G.P., Sasser, C.E., Gosselink, J.G., Rejmanek, M., 1992. Vegetation dynamics in the emerging Atchafalaya Delta, Louisiana, USA. J. Ecol. 80, 677-687.

Shaw, J.B., Mohrig, D., 2013. The importance of erosion in distributary channel network growth, Wax Lake Delta, Louisiana, USA. Geology 42, 31-34. doi:10.1130/G34751.1

Shaw, J.B., Mohrig, D., Whitman, S.K., 2013. The morphology and evolution of channels on the Wax Lake Delta, Louisiana, USA. J. Geophys. Res. Earth Surf. 118, 1562-1584. doi:10.1002/jgrf.20123

Shaw, J.B., Mohrig, D., Whitman, S.K., 2013. The morphology and evolution of channels on the Wax Lake Delta , 118, 1-23. doi:10.1002/jgrf.20123

Shlemon, R.J., 1975. Subaqueous Delta Formation-Atchafalaya Bay, Louisiana. in Deltas: Models for Exploration. Houston Geological Society. Houston, TX. USA. 209-221p.

Syvitski, J.P.M., 2008. Deltas at risk. Sustain. Sci. 3, 23-32. doi:10.1007/s11625-008-0043-3

Syvitski, J.P.M., Kettner, A.J., Overeem, I., Hutton, E.W.H., Hannon, M.T., Brakenridge, G.R., Day, J., Vörösmarty, C., Saito, Y., Giosan, L., Nicholls, R.J., 2009. Sinking deltas due to human activities. Nat. Geosci. 2, 681-686. doi:10.1038/ngeo629

Törnqvist, T.E., Paola, C., Parker, G., Liu, K.-B., Mohrig, D., Holbrook, J.M., Twilley, R.R., 2007. Comment on "Wetland sedimentation from hurricanes Katrina and Rita." Science (80-. ). 316, 201. doi:10.1126/science.1136869

Turner, R.E., Baustian, J.J., Swenson, E.M., Spicer, J.S., 2006. Wetland sedimentation from 
748

749

750

751

752

753

754

755

756

757

758

759

760

761

762

763

764

765

766

767

768

769

770

771

772

773

774

775

776

777

778

779

Tweel, A.W., Turner, R.E., 2012. Landscape-scale analysis of wetland sediment deposition from four tropical cyclone events. PLoS One 7, 1-10. doi:10.1371/journal.pone.0050528

van Heerden, I.L., Wells, J.T., Roberts, H.H., 1983. River-dominated suspended-sediment Deposition in a New Mississippi Delta. Can. J. Fish. Aquat. Sci. 40, 60-71. doi:10.1139/f83-269

Viparelli, E., Shaw, J.B., Bevington, A.E., Meselhe, E., Holm, G.O., Mohrig, D., Twilley, R., Parker, G., 2011. Inundation model as an aid for predicting ecological succession on newlycreated deltaic land associated with Mississippi River Diversions: application to the Wax Lake Delta, in: World Environmental and Water Resources Congress. pp. 2340-2349.

Visser, J.M., 1989. The impact of vertebrate herbivores on primary production of Sagittaria marshes in the Wax Lake Delta, Atchafalaya Bay, Louisiana. Louisiana State University.

Vörösmarty, C.J., Syvitski, J., Day, J., De Sherbinin, A., Giosan, L., Paola, C., 2009. Battling to save the world's river deltas. Bull. At. Sci. 31-44. doi:10.2968/065002005

Walker, N.D., 2001. Tropical storm and hurricane wind effects on water level, salinity, and sediment transport in the river-influences Atchfalaya-Vermillion Bay system, Louisiana, USA. Estuaries 24, 498-508.

Walker, N.D., Hammack, A.B., 2000. Impacts of winter storms on circulation and sediment transport: Atchafalaya-Vermilion Bay Region, Louisiana, U.S.A. J. Coast. Res. 16, 9961010.

Wellner, R., Beaubouef, R., Van Wagoner, J., Roberts, H., and Sun, T. 2005. Jet-plume depositional bodies-the primary building blocks of Wax Lake Delta. Gulf Coast Assoc. Geol. Soc. Trans 55:867-909.

Westerink, J.J., Luettich, R.A., Feyen, J.C., Atkinson, J.H., Dawson, C., Roberts, H.J., Powell, M.D., Dunion, J.P., Kubatko, E.J., Pourtaheri, H., 2008. A basin to channel-scale unstructured grid Hurricane Storm Surge Model applied to Southern Louisiana. Mon. Weather Rev. 136, 833-864. doi:10.1175/2007MWR1946.1

Williams, H.F.L., 2009. Stratigraphy, sedimentology, and microfossil content of Hurricane Rita storm surge deposits in Southwest Louisiana. J. Coast. Res. 254, 1041-1051. doi:10.2112/08-1038.1

Wright, D.L., 1977. Sediment transport and deposition at river mouths: A synthesis. Geol. Soc. Am. Bull. 88, 857-868. doi:10.1130/0016-7606(1977)88 